\title{
HISTORICAL AND PEDAGOGICAL CHRONOLOGY OF THE DEVELOPMENT OF ETHNO-CONFESSIONAL MUSICAL EDUCATION OF MENNONITES IN THE SOUTH OF UKRAINE (END OF THE XVIII - EARLY XX CENTURIES)
}

\author{
Svetlana Brezhnieva \\ Bogdan Khmelnitsky Melitopol State Pedagogical University \\ 20 Getman str., Melitopol, Ukraine, 72312 \\ svetlana_bregneva@ukr.net
}

\begin{abstract}
Historical and chronological principles that the development of musical education of Mennonites in the South of Ukraine (from the end of the 18th century to the beginning of the 20th century) is based on were explained. With the use of archetype and historical-cultural methods of research and implementation of historical and pedagogical reconstruction, an educational-organizational criterion and its indicator (subordination of Mennonite schools) were determined. The main research problem is to maintain the integrity of the ethno-religious Mennonite group among the representatives of the titular nation with the help of spiritual music. The main result: three stages of historical and pedagogical development of musical education of Mennonites in the South of Ukraine were substantiated. The significance of the study is that the deficiency of historical and pedagogical knowledge about the spiritual music education of national minorities, which for centuries lived on Ukrainian lands and influenced the history of musical education in Ukraine, was eliminated.
\end{abstract}

Keywords: history of pedagogy; ethno-confessional music; education; Mennonites; South of Ukraine; end of the 18th early XX centuries.

DOI: $10.21303 / 2504-5571.2018 .00675$

(C) Svetlana Brezhnieva

\section{Introduction}

In the context of the growing identity crisis, there is a scientific interest in the history of musical education of young people, which contains the educational and educational potential of Mennonite spiritual music in the South of Ukraine, which united the community, and gradually formed a collective ethno-confessional identity in the youth based on the performance of hymns at school. During hard times of ethno-confessional life [1], when Mennonites massively immigrated to the United States and Canada from the territories of Ukraine at the beginning of the twentieth century [2], collective identification of the Mennonite group and belonging to the ethno-confessional culture helped them to survive [3]. Hymns were the composition of the ethno-confessional culture as the poetic background of the liturgical service [4], the images that were associated with the completeness of existence and beingness, had been created, and religious traditions had influenced a person since his childhood [5].

The collections of hymns were the main teaching techniques and training resources of spiritual songs. The following collections of hymns were known and kept and preserved in Mennonites families in German language: "Gesangbuch zur kirchlichen und häuslichen Erbauung" (1851); “Deutsches Gesangbuch" (1879); “Geistliche Lieder und Gelegenheitsgedichte" (1880).

The organization of ethno-confessional music education began during the mass migration of Mennonites to the South of Ukraine to the following provinces: Ekaterinoslavskaya (1789-1803) and Tavriyskaya (1804-1820), Khortytsky, Mariupolsky, Molochansky districts (1820) [6].

There was no such musical practice of systematic teaching of children through singing of sacred songs and hymns based on the use of a new musical method of choral singing in schools in the Ukrainian national schools at that time. That practice came from Prussia and was gradually spread in the South of Ukraine. The scientific problem is the development of ethno-confessional musical education of Mennonites in the South of Ukraine (end of 18th - early 20th centuries) and its historical and pedagogical chronology. 


\section{Aim of research}

Justify historical and chronological principles that the development of musical education of Mennonites in the South of Ukraine (from the end of the 18th century to the beginning of the 20 th century) is based on.

\section{Methodology of Research}

The general background of the previous research reflects the scientific interest of researchers in identifying an ethno-religious group of Mennonites living in different parts of the world [7]. The study of the scientific problem of Mennonites [8] has several research trends.

The first research trend: Society and Mennonites, which reflects the interaction of ethnoconfessional Mennonite groups in different societies [9] from the standpoint of history, identity, culture and faith, including Mennonite groups in the South of Ukraine.

Special studies on the life of Mennonites [10] and their residence in the South of Ukraine [11] dated back since 1789. The beginning was as the Golden Age of the pilgrims of faith and it ended in the loss of the Fatherland and the mass migration of Mennonites at the beginning of the 20 th century $[12,13]$. Their hard destiny was associated with the revolutionary events in Russia (1905-1907), the First World War (1914-1917), the October Revolution (1917), their families suffered from famine (1919-1925), they did not accept the philosophy of anarchism [14, 15].

But modern globalization and glocalization processes that take place in the world force Mennonites to overcome the "identity crisis" (Winland, Daphne Naomi 1993), but not to lose identity in a pluralistic society [16].

The second research trend: education and Mennonites, which reflects the relation of ethno-confessional Mennonite groups to the organization of the learning process, modern educational school and the perspectives of solving educational problems in the content of the contemporary cultural paradigm.

It's known from the history that educational reformers such as Johann Cornies (1789-1848) and Philip Wiebe, educators such as Tobias Voth, Heinrich Heese, and Heinrich Franz on the South of Ukraine were the representatives of Meninnite intellectuals [17]. There was also cultural heritage from the Mennonites that lived in Russia [18]. Education was very well organized in the Old Mennonite Colony-Settlement [19], that's why adults constantly took care and payed attention to the youth education [20].

The community of the church, the student's family, school, and communication cultural environment interact with each other to determine the identity of the individual [21].

The third research trend: music and Mennonites, their identification by means of music culture.

Traditional musical culture of Mennonites was preserved until the middle of the nineteenth century [22]. Mennonites music helps to keep the identity of the group, but it becomes more an individual music activity of a person than a group one [23]. It is proved that social capital can influence choir culture and guarantee positive interaction of the choir participants [24]. Amish and their children maintain traditional cultural values through the performance of spiritual songs [25].

Sample of Research

The following documents were analyzed in order to determine historical and pedagogical chronology of the ethno-confessional musical education development of the Mennonites in the South of Ukraine (end of 18th - early 20th centuries):

1) archival documents (State Archive of the Odessa Region; State Archive of the Zaporp izhzhia Region; Russian Federation State Archive);

2) funds of the Museum of History of the Zaporizhzhia Cossacks at the National Reserve "Khortytsya" (Zaporizhzhia, Ukraine). Historical analysis of pre-revolutionary regional periodicals has been conducted: newspapers "Aleksandrovskie otkliki"; "Aleksandrovskiy vestnik"; "Aleksandrovskiy golos"; "Melitopolskie vedomosti"; provincial periodicals "Vestnik Yuga"; «Dneprovskaya molva», «Dobra porada», «Ekaterinoslavskaya zemskaya gazeta», «Ekaterinoslavskie gubernskie vedomosti», «Ekaterinoslavskiy listok»; «Kryimskiy vestnik», «Kryimskiy 
kurer», «Russkaya rivera», «Tavrichanin», «Yuzhnyie vedomosti», «Tavricheskie gubernskie vedomosti».

Based on the analysis of archival documents such as: Funds of the State Archive of the Odessa Region (F. 89; F. 252); Funds of the Russian State Historical Archive (F. 1287); Funds of the State Archive of the Zaporizhzhia Region (F. 236; F. 237; F. 238; F. 23; F. 58; F. 153; F. 183; F. 250; F. 251; F. 256) and regional periodicals, the organizational-educational criterion and its index (subordination of Mennonite schools) were developed. This criterion was used to describe three historical and pedagogic chronological periods of the ethno-confessional musical education of the Mennonites development in the South of Ukraine.

Let's determine the following: the first chronological stage (1789-1842). The Mennonites' schools were subordinated to the Mennonite Protestant Church which took control over education including ethno-confessional musical education. The second chronological stage (1843-1880). Mennonites' Schools were subordinated to the education community of Mennonite colonists, as shown in the work of G. Franz "The Constitution for the Union of Khortytsia Schools" (1846), which regulated the content of activities. The third chronological stage (1881 - the beginning of the XX century). Mennonites' Schools were subordinated to the Ministry of Public Education.

\section{Methods of the Research}

The following methods were used:

- archetype method - to reveal the content of the artistic and pedagogical concept of "ethno-confessional music of Mennonites" in terms of the conceptual apparatus (churches, culture, ethnos);

- historical and cultural method - to study the phenomena, events, cultural process of the ethno-confessional musical education of the Mennonites in the context of that time and the socio-economic conditions in which they occurred, the opposition to the simplification and vulgar description of the historical and cultural processes of the study period;

- historical and pedagogical reconstruction - for consideration of the achievements of ethnoconfessional musical education of Mennonites in the region and reconstruction of the main historical and pedagogical factors that directly influenced the content and development of ethnoconfessional musical education of Mennonites in an anti-ethnic environment.

\section{Results}

The historical and pedagogical chronology of the development of ethno-confessional musical education of Mennonites in the South of Ukraine in three stages is described.

Unknown books, textbooks, pedagogical manuals for chorus for music teachers and pupils appeared on the territory of Ukraine with Mennonites during the first chronological stage (1789-1842). The author of those unknown books was G. Nägeli (Hans Georg Nägeli): «Teaching singing based on Pestalozzi methods» (in German «Gesangsbildungslehre nach Pestalozzischen Grundsätzen», 1810), «Teaching singing for male choir» (in German «Gesangbildungslehre für den Männerchor», 1817), «School of choral singing» (in German «Chorgesangschule», 1821), «Practical School for female choir singing» (in German «Praktische Gesangsschule für den weiblichen Chorgesang», 1832) and others which were present in Mennonites elementary schools in the South of Ukraine (Letkemann, P. 1986).

The «Musical and Pedagogical Concept of Natorp» (1813, 1820, Prussia) was published for the first time in Europe, which marked the beginning of the development of musical education of youth, including Mennonites, in schools in the South of Ukraine.

The author B. Ch. L. Natorp (Bernhard Christoph Ludwig Natorp) published a revised and expanded edition of the first part of the manual and presented examples of music in figures (numbes) and in song notations at the same time (1816). The "Pedagogical method of Natorp" was becoming more and more popular in the musical education of young people.

Musical reformation of chants began in the village Gnadenfeld in the Molochansky Mennonite District under the guidance of G. Franz, a schoolteacher of chants who came from Prussia. In order to preserve all the best that was in the tradition of singular singing he began the restoration of 
Mennonites melodies, as well as improved and facilitated school singing (the beginning of reform took place in 1837 and ended in 1865). He believed that the oral interpretation of the unwritten melody led to the fact that through the generation the melody itself was wrong and ruined. It was difficult for the choir to perform the melodies. According to his point of view something should had been done in order to renew original melodies and rhythms for hymns performance. He began working on singing in four voices (quatrains) (developing scores for choir).

The content of the academic curriculum of the Mennonite schools reflected singing, performing of choir melodies according to the figures (numbers) (1822-1842). The main musical educational idea was christocentrism. Suffering and pain predominated in the content of the youth spiritual songs. Teaching methods in the ethno-confessional musical education were the following: collections of hymns, spiritual songs of different editions in German for adults which came from Prussia or were kept by Mennonites. There were also hymns created especially for children (1742, 1747). Such words as the blood of Christ, suffering were deleted from the children hymn texts. The Central school on the Island of Khortytsya was connected with the history of the performance of the Mennonite hymn supervised by the teacher G. Franz (1846-1858).

The second chronological stage (1843-1880). The document for a standardized academic curriculum for Mennonite village schools by J. Cornis was first published, where a song Ziffern (cipher-notation) from the Gesangbuch was included. For the first time students learned how to read music in a Ziffern notation.

J. Cornis constantly disseminated the singing of Ziffern notation at the Mennonite Schools in the South of Ukraine. The introduction and study of the Ziffern system in many Mennonite schools offered a new singing style called Zifferngesang (Number Singing) (1850s). During the period of introduction of new teaching methods, including musical education, they were strongly criticized by the public, teachers and parents (1850s) [26].

Gradually a radical change in the style of performing hymns was taking place, a high-quality choral culture and a growing number of church and school choirs in the Northern Priazov'ie were disseminated and widely spread (1860). The first documented Minutes of singing in numbers and figures were in the Russian Mennonite schools (from 09.02.1860).

The teacher Isaac Klassen was very critical to the teachings of Zahlengesang [singing numbers; singing in figures] comparing such ethno-confessional musical education with the work of the antichrist in the end of times (1869), and did not accept it, he actively opposed that musical innovation. The teaching method of Zahlengesang [singing numbers; singing in figures] was not supported and it was in opposition (1870s, Report by Lars Petersen, pseudonym David H. Epp).

The Mennonite teaching and education was in Russian. German language was used for God's Law, songs, history of religions. Reading and writing was taught in both languages (1871).

The main music idea: polyphonic choral singing and its improvement on religious-musical traditions. Ethno-confessional tradition of unison singing without musical instrumental accompaniment was widely used by youth (1874). The content of the youth spiritual songs reflected the joy of life through suffering.

The methods of teaching used in ethno-confessional musical education were the following: collections of hymns, spiritual songs of canonized and non-canonized content in their native language (in Prussia).

The third chronological stage (1881 - the beginning of the XX century). Musical education of schoolchildren of Mennonites schools was based on a new method of teaching.

The program (academic curriculum) of music and songs in Neizatske Central Specialized School (College) (Autonomous Republic of Crimea, 1893) was the following: two lessons per week were for the songs (on Monday and Friday) [27].

Students studied 15 church topics during a school year with the division of students in voices, they also knew the theory of music. The musical educational idea: internalization which meant the acceptance of the society values for social harmonization during childhood; harmony among children and parents based on the Protestant religion and improvement of many-voiced choral skills by performing spiritual songs and hymns. The content of the youth spiritual songs: encouragement for good, the addition of forces in the struggle against temptations in earthly life. 
The means of teaching in ethno-confessional musical education: collection of hymns and spiritual songs.

Author's spiritual songs for children: «Echo from Heaven» (Barney E. Warren, 1893); («Give Me Jesus Alone») (Daniel O. Teasley, 1907); the hymn «Keep Me» (Charles W. Naylor, 1907).

\section{Discussion}

The historical-pedagogical chronological beginning of the development of ethno-confessional musical education of Mennonites in the South of Ukraine as theoretical and methodological (1789-1842) was first established and characterized. The proof of this statement is the following: publications of musical and pedagogical work of H. Nägeli (Hans Georg Nägeli) (1810, 1817, 1821, 1832); «Musical and pedagogical concept of B.Ch.L. Natorp» (1813) and his pedagogical method. That meant that a child's voice could be even, flexible and sonorous, if it's accustomed to the rhythm and harmony of music, and the musical language could be accessible to children at school.

The development of Mennonites ethno-confessional education as vocal and practical (1843-1880) was determined and characterized. The proof is the following: pedagogical method of Natorp was introduced in Mennonites elementary schools, the teacher G. Franz carried out the restoration of Mennonite melodies in 1837-1865 (hymns, spiritual and folklore songs). The content of the academic curriculum reflected songs, performance of choral parties by numbers (1822-1842) in the South of Ukraine; the academic curriculum for Mennonites village schools was standardized and documented the organization of singing by Ziffern method (by numbers) (J. Cornis). Public choral culture was widely spread and disseminated at schools in the South of Ukraine.

The flowering of the development of ethno-confessional musical education of Mennonites in the South of Ukraine (1881 - the beginning of the 20th century) was determined and characterized. The proof is the following: Choral singing of children in the schools of Mennonites using new musical teaching methods was becoming widespread (1881 - the beginning of the 20th century), there were positive results of assimilation of the theory of music by young people, and the quality of the practical performance of the hymns by the children in the choir. The number of school choirs of Mennonites in the South of Ukraine was growing significantly and had a high level of performance of songs.

\section{Conclusions}

The study provides grounds for such conclusions:

1. The ethno-confessional musical education of the Mennonites is a deliberate process and the result of the mastering of centuries-old canonized musical art is considered.

2. The ethno-confessional musical education as a polyphonic sound symbol of the unity of people and the church, which merges with the performance of hymns, directs the energy of people for the upbringing of their souls; it is a «social educator» of the younger generation.

3. Ethno-confessional musical education preserves a person, its identity in other spiritual territories - the South of Ukraine (end of the 18th - early XX centuries).

4. Historical and pedagogical chronology of the development of ethno-confessional musical education of Mennonites in the South of Ukraine (end of the 18th - early XX centuries) proves that music and faith are closely interconnected. Spiritual music contributes to the strengthening of faith, and faith gives musical inspiration in the performance of hymns. The Apostle Paul instructed the Colossians, «... with gratitude in your hearts sing psalms, hymns, and spiitual songs to God. And whatever you do, in word or deed, do everything in the name of the Lord Jesus, giving thanks to God the Father through him» (Col. 3: 16-17).

\section{Acknowledgements}

The author of this article expresses its deep gratefulness to J. Dyck for the advice during this historical and pedagogical research and to P. Letkemann for a kind opportunity to read the text of the dissertation and use it as Reference. 


\section{References}

[1] Bergen, E. (1992). Historical Background of the Martin Klaassen Family. Mennonite Historian, XVIII (3), 1-2.

[2] Friesen, J. (Ed.) (1989). Mennonites in Russia, 1788-1988: Essays in Honour of Gerhard Lohrenz. Winnipeg: CMBC Publications, 1989.

[3] Belk, F. R. (1976). The Great Trek of the Russian Mennonites to Central Asia 1880-84. Scottdale, 252.

[4] Bender, H., Harold, S. (1956). Hymnology of the American Mennonites. The Mennonite Encyclopedia. Vol. 2. Scottdale, 147, 879-886.

[5] Browning, D. S., Bunge, M. J. (2009). Children and Childhood in Word Religions. New Brunswick, 233.

[6] Friesen, J. (1994). Against the Wind: The Story of Four Mennonite Villages (Gnadental, Gruenfeld, Neu-Chortitza and Steinfeld) in Southern Ukraine, 1872-1943. Winnipeg: Henderson Books, 165.

[7] Urry, J. (2006). Mennonites, Politics, and Peoplehood. Europe - Russia -Canada: 1525 to 1980. Winnipeg: Man, 400

[8] Loewen, H. (1990). Intellectual Developments Among the Mennonites of Russia: 1880-1917. Journal of Mennonite Studies, 8, 89-107.

[9] Postma, J. S. (1959). Das niederländische Erbe der preußisch-rußländischen Mennoniten in Europa, Asia und Amerika. Leeuwarden, 274.

[10] Rempel, D. (1933). The Mennonite colonies in New Russia: a study of their Settlement and economic development from 1789 to 1917. Stanford: Stanford University.

[11] Goerz, H. (1993). The Molotschna Settlement. Winnipeg: CMBC Publications and Manitoba Mennonite Historical Society, 252.

[12] Toews, J. B. (1967). Lost Fatherland: The Story of the Mennonite Emigration from Soviet Russia, 1921-1927. Scottdale: Herald Press, 262.

[13] Toews, J. B. (1975). Selected Documents: The Mennonites in Russia from 1917 to 1930. Winnipeg: Christian Press.

[14] Dyck, H. L.; Friesen, J. (Ed.) (1989). Landlessness in the Old Colony: The Judenplan Experiment 1850-1880. Mennonites in Russia 1788-1988. Essays in Honor of Gerhard Lorenz. Winnipeg, 183-201.

[15] Ehrt, A. (1931). Das Mennonitentum in Ruland von seiner Einvanderung bis zur Gegenwart. Berlin, 175.

[16] Toews, P. (Ed.) (1993). Mennonites and Baptists : a continuing conversation. Winnipeg: Kindred Press, 261.

[17] Loewen, H. (1990). Intellectual Developments Among the Mennonites of Russia: 1880-1917. Journal of Mennonite Studies, 81, 89-107.

[18] Reimer, A. (1989). The Print Culture of the Russian Mennonites 1870-1930. Mennonites in Russia 1788-1988. Winnipeg, Manitoba.

[19] Crocker, W. (2017). Schooling across Contexts: The Educational Realities of Old Colony Mennonite Students. Journal of Amish and Plain Anabaptist Studies, 4 (2), 168-182. doi: http://doi.org/ $10.18061 / 1811 / 79934$

[20] Gingerich, M. (1989). Elementary Education. Mennonite encyclopedia. Vol. 2. Hillsboro, 19551959, 181-183.

[21] Dabback, W. (2016). A community of singing: motivation, identity, and communitas in a Mennonite School choir programme. Music Education Research, 20 (2), 242-251. doi: http://doi.org/10.1080/146 13808.2016.1257593

[22] Berg, W. (1996). Hymns of the Old Colony Mennonites and the Old Way of Singing. The Musical Quarterly, 80 (1), 77-117. doi: http://doi.org/10.1093/mq/80.1.77

[23] Dueck, J. (2005). Worship Wars, World Music,and Menno-Nots: Recent Studies in Mennonite Music. Journal of Mennonite Studies, 23, 123-136.

[24] Langston, W. T. (2011). It is a life support, isn't it? Social capital in a community choir. International Journal of Community Music, 4, 163-184. doi: http://doi.org/10.1386/ijcm.4.2.163_1

[25] Elder, D. R. (2001). «Es Sind Zween Weg»: Singing Amish Children into the Faith Community. Cultural Analysis: An Interdisciplinary Forum on Folklore and Popular Culture, 2, 39-67.

[26] Letkemann, P. (1986). The hymnody and choral music of Mennonites in Russia, 1789-1915. Toronto, 140.

[27] Goerz, H. ( 1992). Mennonite Settlements in Crimea. Winnipeg: CMBC Publications and Manitoba Mennonite Historical Society. 